\title{
Heavy Metal Concentration in Neotropical Aquatic Snakes (Helicops Pastazae) and Its Potential as a Bioindicator of Water Pollution
}

María Jose Hurtado-Morales ( $\sim$ mj.hurtado10@uniandes.edu.co )

Universidad de Los Andes Facultad de Ingenieria https://orcid.org/0000-0001-7472-3509

Manuel Rodríguez

Universidad de Los Andes

Adolfo Amezquita

Universidad de Los Andes

\section{Research Article}

Keywords: Heavy metals, bioaccumulation, tissues, biological indicator, water quality, Helicops pastazae

Posted Date: June 1st, 2021

DOI: https://doi.org/10.21203/rs.3.rs-291191/v2

License: (c) (1) This work is licensed under a Creative Commons Attribution 4.0 International License.

Read Full License

Version of Record: A version of this preprint was published at Archives of Environmental Contamination and Toxicology on January 31st, 2022. See the published version at https://doi.org/10.1007/s00244-02200911-0. 


\section{Abstract}

The purpose of the present study was to test the potential role of the aquatic snake Helicops pastazae as indicators of water pollution caused by heavy metals. In particular, we tested whether the total heavy metal concentration is related to (1) the position (upstream vs downstream) of the sampling point and its distance from the point where wastewater is discharged; (2) the taxonomic group studied and its place in the trophic chain: piscivorous snakes vs characid fish that co-occur with them; and (3) the organ or tissue examined: snake liver versus muscle. We quantified cadmium (Cd), chromium $(\mathrm{Cr})$ and lead $(\mathrm{Pb})$ by using atomic absorption spectrophotometry with electrothermal atomization. Significant differences were found between some of the sampling points, particularly high metal concentrations were detected upstream at point 1, but no clear spatial pattern was found. There were no significant differences in the concentration of any of the metals between fish and snake muscle, suggesting potential mechanisms of metal excretion in snakes. With regard to interactions, the snake liver had the highest concentrations of cadmium and the muscle of lead and chromium, which may indicate tissue affinity differences for certain metals. Altogether, our results indicate that $H$. pastazae accumulates contaminants differentially, depending on the tissue and location, which render them useful bioindicators of water contamination.

\section{Introduction}

Domestic or industrial wastewater discharge has severe impacts on communities of aquatic organisms, leading to a decrease in water quality, which, in turn, potentially affects public health, flora, and fauna. One of the main environmental problems related to aquatic ecosystems is pollution by heavy metals produced by point discharges or diffuse sources to bodies of water, mineralization of rocks, or mining activities upstream of a water system (Macías 2015).

Heavy metals are natural elements found in the Earth's crust, which in trace quantities play a positive role on the life of organisms; in very high concentrations, however, they are usually toxic. Because of their high toxicity and difficult transformation, they bioaccumulate in aquatic organisms, negatively affecting physiological performance and ecological interactions (Zorrilla 2011). Initially they are assimilated by phytoplankton and filter organisms and subsequently incorporated into the trophic chain, increasing their concentration as they are ingested by higher trophic-level organisms (Márquez et al. 2008). Due to their chemical stability, living beings cannot metabolize heavy metals, which further explains their bioaccumulation until reaching high levels of toxicity. They are also efficiently absorbed through biological membranes due to their high chemical affinity with the sulfhydryl group (-SH) present in proteins (Mancera-Rodríguez and Álvarez-León 2006).

The heavy metals of higher ecotoxicological importance in aquatic environments are mercury, arsenic, chromium, lead, cadmium, nickel and zinc; their ionic forms enter the cell through metal cation transport systems. Their toxicity and uptake depend on concentration, exposure time, and various environmental factors (Zorrilla 2011). One of the main causes of their chemical toxicity is based on their ability to bind with organic molecules, based on reactions with specific ligands, namely sulfhydryl groups, and amino, 
phosphate, carboxyl and hydroxyl radicals. The resulting organometallic complexes may inhibit structural changes being made to protein, and thereby affect the transport of essential elements and the metabolism of reactive oxygen species or of free radicals related to oxidative stress, among others (Zorrilla 2011).

Snakes may serve as biological indicators of environmental pollution, given their position as primary or secondary predators, their restricted migration, and their long life cycle (Heinz et al. 1980; Campbell and Campbell 2001; Burger et al. 2005, 2007, 2017; Albrecht et al. 2007). However, despite the potential value of aquatic snakes as bioindicators, they are not commonly used in environmental pollution studies (Burger 2005, 2007; Campbell and Campbell 2001, 2005; Heydari and Riyahi 2015). Helicops pastazae (Colubridae), distributed from Colombia to Argentina (Uetz et al. 2019), has semi-aquatic habits, as evidenced in adaptations to their nostrils and eyes in dorsal position and keeled scales (Segall et al. 2016). Snakes in this genus are considered to be at the top of the food chain, feeding on fish, anurans, lizards and other snakes. Although there is a lack of information on the specific diet of H. pastazae, it is thought to feed on fish and to be an opportunistic predator (Almendáriz et al. 2017).

To assess its potential as a bioindicator, the purpose of the present study was to estimate the concentration of heavy metals in different tissues of $H$. pastazae, and to compare bioaccumulation in this predator and the fish species it potentially feeds on. The sampling site covered a section of the Batá river (eastern Colombian Andes), which receives residual water from the sewage system of the municipality of Santa María, through the streams of La Argentina, El Toro and Caño Cangrejo, where there is no liquid waste treatment and the networks are in poor condition (Corpochivor 2003). Upstream from this section, the river receives water from the Chivor reservoir, which probably concentrates the contamination by sediments, residues, and dissolved nutrients (Corporación Autónoma Regional de Cundinamarca et al. 2006). Given that the Bata river is home to a various species of fauna, that there are no studies on heavy metals in this area, and that snakes can potentially serve as bioindicators, a study was undertaken to quantify total cadmium, lead and chromium concentrations in the liver and muscle of Helicops pastazae snakes, as well as in fish muscle.

The following hypotheses were tested: 1) The total heavy metal concentration depends on the position (upstream vs downstream) of the sampling point and its distance from the point where wastewater is discharged, and is expected to be greater downstream from the discharge point. 2) The total heavy metal concentration depends on the taxonomic group studied and its place in the trophic chain, and will be higher in piscivorous snakes than it will in fish. And 3) it also depends on the organ or tissue examined, and is presumably higher in the liver compared to the muscle.

\section{Methods}

\section{Study site}


Four sampling points were selected, two upstream of the wastewater discharge (known as Caño Cangrejo), and two downstream the municipality of Santa María (Fig. 1 and Fig. 2). The sampling was carried out in the months of January and February.

The procedures for euthanasia and manipulation of individuals were approved on October 18, 2018 by the Institutional Committee for the Care and Use of Laboratory Animals (CICUAL) by analyzing the animal use format COR_C.FUA_18 - 016. Individuals were collected under the permit: "Permiso Marco de Recolección de Especímenes de Especies Silvestres de la Diversidad Biológica con Fines de Investigación Científica No Comercial," certified under research project PR.6.2018.4967 "Integración de rasgos funcionales y moleculares en estudios evolutivos de comportamiento y fisiología," with mobilization permit P04967S3591_N0004.

Snakes were found and collected under rocks along the rivers' edge, during the day. Most individuals were adult (length greater than $30 \mathrm{~cm}$ ), but juveniles were also collected where finding adults became difficult. Individuals were euthanized by intracardiac injection of $3-5 \mathrm{~mL}$ of $2 \%$ xylocaine anesthetic for adults, and a 1-2 $\mathrm{mL}$ dose for juveniles. This euthanasia process is approved by the AVMA (American Veterinary Medical Association) and guarantees a non-traumatic death. Subsequently, tissues were extracted and later preserved in a refrigerator with ice until arrival at the laboratory, always within $48 \mathrm{~h}$.

An unidentified fish species, belonging to the family Characidae, was abundant in the study area, and thought to be part of the snakes' diet given its size and distribution along the riverbanks. They were collected during the day on the riverbank and using a net. They were euthanized by freezing, to be preserved until they reached the laboratory.

We chose to sample three metals of ecotoxicological importance (Henze et al. 2002): chromium, lead, and cadmium. The geological baseline of the municipality of Santa María reveals the presence of clays, sandstones, gypsum, limolites, among others, which generate mostly iron and aluminum derivatives (Corpochivor 1996).

\section{Analytical methods}

All standard solutions and elements dilutions were prepared in ultrapure water (resistivity of approximately $18 \mathrm{M} \Omega \cdot \mathrm{cm}$ ). All solutions were prepared daily by direct dilution in deionized water and high purity nitric acid. Glassware and polypropylene flasks were submerged in $5 \%\left(v \cdot v^{-1}\right)$ nitric acid for 24 hours, followed by rinsing with deionized water before analysis. The stock solutions were prepared using 1000 ( $\mathrm{mg} \mathrm{L}^{-1}$ ) commercial standards of $\mathrm{Cd}, \mathrm{Pb}$ and $\mathrm{Cr}$ (PanReac Applichem, Spain). All dilutions were acidified by $0.5 \%\left(v \bullet v^{-1}\right)$ nitric acid $(65 \% \mathrm{RE}$, Pure) purchased from Carlo Erba, Italy. Ammonium dihydrogen phosphate and nitrate magnesium modifiers used in the analysis: $\mathrm{NH} \otimes \mathrm{H} \otimes P O \bigotimes\left(100 \pm 2 \mathrm{~g} \cdot \mathrm{L}^{-1}\right)$ in $\mathrm{H} \otimes \mathrm{O}$ and $\mathrm{Mg}(\mathrm{NO} \otimes) \otimes \bullet 6 \mathrm{H} \otimes \mathrm{O}\left(10.0 \pm 0.2 \mathrm{~g} \bullet \mathrm{L}^{-1}\right)$ in $\mathrm{HNO}$ (ca. $\left.17 \%\right)$, were commercially acquired from Supelco (Germany). 
Analytical measurements were made in an HR-CS-AAS, CONTRAA 800D (Analytik Jena, Germany) transversally heated graphite furnace. High purity argon at $2 \mathrm{~L} \cdot \mathrm{min}^{-1}$ as operation inert gas and pyrolytically coated graphite tubes with L'Vov platform were used (Analytik Jena Part No. 407-A81.025). Each element was analyzed according to default conditions recommended in the apparatus software as "cook-book" settings. Table 1 and Supplementary Information 1 present the instrumental operating lines, heating programs, and chemical modifier for each element. All measurement was made in triplicate sample injection by 108 positions AS-GF autosampler.

Table 1

Equipment working conditions to determine $\mathrm{Cd}, \mathrm{Pb}$ and $\mathrm{Cr}$

\begin{tabular}{|llll|}
\hline Parameter & Cadmium & Lead & Chromium \\
\hline Analytical line of work $(\mathrm{nm})$ & 228.8018 & 283.306 & 357.8687 \\
\hline Pixels in detector used for measurement & $3(\mathrm{CP} \pm 1)$ & $3(\mathrm{CP} \pm 1)$ & $3(\mathrm{CP} \pm 1)$ \\
\hline Standard or sample solution volume $(\mu \mathrm{L})$ & 20 & 20 & 20 \\
\hline Specific modifier & $\mathrm{NH}_{4} \mathrm{H}_{2} \mathrm{PO}_{4}$ & $\mathrm{NH}_{4} \mathrm{H}_{2} \mathrm{PO}_{4}$ & $\mathrm{Mg}\left(\mathrm{NO}_{3}\right)_{2}$ \\
\hline Mass spiked with $5 \mu \mathrm{L}$ to solution $(\mu \mathrm{g})$ & 50 & 50 & 5 \\
\hline
\end{tabular}

\section{Sample preparation and laboratory procedures}

Sample preparation and digestion was performed using a modified EPA method 3052 (EPA 1996), adjusted on the basis of preliminary tests. Each individual was washed with deionized water to remove dirt and external contamination on the skin (Burger 1992). To obtain the sample for the snakes, muscle and liver tissue were extracted from the individuals via $2 \mathrm{~cm}$ longitudinal incision made ventrally in the middle of the body, using a ceramic scalpel and stainless-steel tweezers to avoid traces of metals and pollution (FAO/SIDA 1983). In the case of fish, muscle tissue was removed by making an incision above the lateral line, between the dorsal and caudal fins (Queensland Government 2018). The material was stored in plastic containers previously washed and sterilized with $5 \%$ nitric acid and deionized water and was subsequently refrigerated at $-17^{\circ} \mathrm{C}$ until digestion and respective analysis (FAO/SIDA 1983). The digestion procedure followed a Microwave Assisted Acid Digestion of Siliceous and Organically Based Matrices (EPA 1996), which consisted of weighing the solid material, and then adding $10 \mathrm{~mL}$ of concentrated $\mathrm{HNO}_{3}$ to it.

We proceeded to weigh each of the samples in the vials to carry out the digestion, and to later estimate the concentration of metal per unit mass. Following this, each sample was predigested for 1 hour by adding $10 \mathrm{~mL}$ of concentrated nitric acid, allowing the vessels to release gases. Subsequently the samples were put in the microwave, completely sealing the vials. The temperature of each sample rose to $180^{\circ} \mathrm{C}$ in approximately 5.5 minutes and remained at this temperature for 9.5 minutes until complete decomposition, followed by a cooling step. At the end of the microwave program, the samples were left to cool for 5 minutes before extraction. When the seals were removed from each vial, the sample was 
filtered, and $5 \%$ nitric acid was added to complete $10 \mathrm{~mL}$ in case of volume loss (EPA 1996). All metal concentrations are expressed in $\mu \mathrm{g} / \mathrm{g}$ of wet tissue weight. The heavy metals were measured using a ContrAA® atomic absorption spectrometer, with electrothermal atomization, taking into account the measurement of standard samples of known concentration and blanks to be able to estimate the specific calibration curve (Burger 1992). For quantification, $25 \mu \mathrm{L}$ of sample was diluted in $1 \mathrm{~mL}$ of deionized water (25:1000), and following the measurement, each concentration obtained had to be multiplied by 40 . The detection limits, calculated using at least 10 targets, were (in $\mu \mathrm{g} / \mathrm{g}$ ) 0.00009 for chromium, 0.0000008 for cadmium, and 0.000042 for lead.

\section{Statistical analysis}

All statistical analyses and graphics were performed using the R software (R Core Team, 2013), as implemented in RStudio. Multivariate and univariate normality tests were performed for each set of continuous data. When they did not meet the assumptions of normality and homogeneity of variances and could not be transformed to achieve a normal distribution, non-parametric tests were used.

The Spearman non-parametric correlation test was used to assess the correlation between the concentration of the analyzed metals. On the other hand, to model the possible relationship between the concentration of metals in each tissue and the body mass of the snakes a generalized linear model (GLM) with a Poisson link was built, given that the output variable (concentration) has a lower distribution limit than 0 .

To test whether the concentration of each metal was predictable from the type of organism (snake or fish), the type of snake tissue (liver or muscle), and the sampling point (the position with respect to the wastewater discharge point in the river), linear models following a Bayesian approach were built. A Gamma Hurdle distribution was assumed, which makes it possible to analyze continuous data that includes a large number of zeros (i.e. zero-inflated data).

\section{Results}

A total of 28 Helicops pastazae individuals and 28 individuals of fish from the Characidae family were collected; 7 individuals of each species at each sampling point (Fig. 2). Female snakes weighed on average $78.71 \pm 44 \mathrm{~g}$ and measured on average $43.4 \pm 11 \mathrm{~cm} \mathrm{SVL}$, while the males weighed on average $39.28 \pm 21 \mathrm{~g}$ and measured on average $33.7 \pm 6 \mathrm{~cm}$ SVL. Juveniles (measuring a total length of less than $30 \mathrm{~cm}$, which was estimated based on the smallest female that could be sexed) weighed on average 5.42 $\pm 0.5 \mathrm{~g}$ and measured on average $16.3 \pm 0.6 \mathrm{~cm}$ SVL.

Snake body mass was inversely correlated with chromium concentrations $(Z=-2.411, p=0.0159, n=83$ samples, correlation coefficient=-0.02995) (Fig. 3c), but not with lead or cadmium. On the other hand, the pairwise correlation among the concentration of heavy metals was far from significant $(-0.0826<$ Spearman correlation coefficient $<0.0995$ and $\mathrm{P}>0.37$ in all cases), which means that individuals with a high concentration of a particular metal do not necessarily have a high concentration of the other metals. 
Table 2

Heavy metal concentration in different tissues taken from fish and snakes from the Bata river (arithmetic mean \pm standard deviation in $\mu \mathrm{g} / \mathrm{g}$ wet weight).

\begin{tabular}{|lllll|}
\hline & n & Cadmium & Lead & Chromium \\
\hline Fish & & & & \\
\hline Muscle & 28 & $0.012 \pm 0.038$ & $0.492 \pm 0.790$ & $1.168 \pm 1.536$ \\
\hline Snake & & & & \\
\hline Muscle & 27 & $0.001 \pm 0.002$ & $0.601 \pm 1.970$ & $0.779 \pm 0.728$ \\
\hline Liver & 28 & $0.006 \pm 0.010$ & $0.127 \pm 0.189$ & $0.517 \pm 0.824$ \\
\hline
\end{tabular}

Table 3

Heavy metal concentration in different tissues taken from fish and snakes at different points in the Bata river (arithmetic mean \pm standard deviation in $\mu \mathrm{g} / \mathrm{g}$ wet weight).

\begin{tabular}{|c|c|c|c|c|c|}
\hline & Sampling point & $\mathbf{n}$ & Cadmium & Lead & Chromium \\
\hline \multicolumn{6}{|l|}{ Fish } \\
\hline \multirow[t]{4}{*}{ Muscle } & 1 & 7 & $0.003 \pm 0.004$ & $0.469 \pm 0.358$ & $0.387 \pm 0.406$ \\
\hline & 2 & 7 & $0.010 \pm 0.025$ & $0.343 \pm 0.385$ & $1.714 \pm 1.531$ \\
\hline & 3 & 7 & $0.034 \pm 0.071$ & $0.986 \pm 1.438$ & $2.199 \pm 2.208$ \\
\hline & 4 & 7 & $0.001 \pm 0.003$ & $0.170 \pm 0.171$ & $0.373 \pm 0.436$ \\
\hline \multicolumn{6}{|l|}{ Snake } \\
\hline \multirow[t]{4}{*}{ Muscle } & 1 & 6 & $0.0013 \pm 0.0031$ & $0.210 \pm 0.211$ & $0.749 \pm 0.828$ \\
\hline & 2 & 7 & $0.0005 \pm 0.0015$ & $1.808 \pm 3.798$ & $0.628 \pm 0.784$ \\
\hline & 3 & 7 & $0.0003 \pm 0.0008$ & $0.209 \pm 0.106$ & $0.521 \pm 0.453$ \\
\hline & 4 & 7 & $0.0006 \pm 0.0015$ & $0.120 \pm 0.220$ & $1.292 \pm 0.703$ \\
\hline \multirow[t]{4}{*}{ Liver } & 1 & 7 & $0.008 \pm 0.018$ & $0.312 \pm 0.243$ & $0.206 \pm 0.949$ \\
\hline & 2 & 7 & $0.004 \pm 0.004$ & $0.071 \pm 0.138$ & $0.271 \pm 0.238$ \\
\hline & 3 & 7 & $0.011 \pm 0.005$ & $0.048 \pm 0.046$ & $0.082 \pm 0.122$ \\
\hline & 4 & 7 & $0.002 \pm 0.004$ & $0.077 \pm 0.166$ & $0.909 \pm 1.232$ \\
\hline
\end{tabular}

Considering each sampling point, significant differences were only observed for chromium at point 4, where the concentrations were higher in the snakes than they were in fish (Fig. 4). Fish muscle revealed a higher average concentration of the analyzed metals than the concentration found in the snake muscle. 
There is no significant difference in cadmium, chromium, and lead concentrations found in fish and snake muscle (Fig. 5).

No significant differences were found between the concentration of different metals in the same tissue (Table 2). For cadmium, significantly higher concentrations were found in snake liver than in snake muscle (Fig. 6, Fig. 7a), and lead and chromium concentrations were significantly higher in the muscle (Fig. 6, Fig. 7b, Fig. 7c). These patterns remain when comparing the average concentrations of metals for each of the river points analyzed (Table 3 ).

When comparing the difference in terms of the sampling points upstream and downstream from the water discharge point, higher chromium and cadmium concentrations were found in fish and snake muscle at point 3 than at point 1, and higher lead concentrations at point 2 than at points 1 and 4 (Fig. 5). On the other hand, when analyzing snake tissue, point 1 led to higher concentrations for all metals in comparison to at least one of the other points (Fig. 7). This reveals that no clear spatial pattern was found.

\section{Discussion}

The frequency of females, males and juveniles was variable at each sampling point (Fig. 2). An attempt was made to collect only adult individuals but some juveniles had to be captured given that in some points not enough adults were found. Although the juvenile condition could imply less bioaccumulation of metals, this pattern did not appear in the analyses. There was no evidence of umbilical cord and some of the juveniles were shedding their skin. This growth indicator evinces that food intake has taken place and considering that it is through diet that the snakes are exposed to metals (Lemaire et al. 2018; Hopkins et al. 2001), it could be concluded that metal bioaccumulation takes place even with just a few ingested animals.

\section{Comparison between sampling points}

Two statistical models were developed to assess whether there were differences between sampling points: one considering the organism and another considering the type of tissue. In the first model, significant differences were obtained for chromium and cadmium concentration, which were higher at point 3 than point 1 (Fig. 5). In the second model, lower concentrations were observed near the water discharge zone, particularly at point 3 for lead and chromium (Fig. 7). This may indicate that both snake liver and muscle are tissues that can reveal differences in concentrations along the river. It can be noted as a general trend that metal concentrations are higher in point 1 when analyzing snake tissue.

The absence of a spatial gradient in the concentration of metals, expected to be lower upstream of the wastewater discharge point and higher downstream, may be due to the Bata river being located downstream of the Chivor reservoir, which receives sewage from the basin and has dammed waters that are highly contaminated by sediments, residues, and dissolved nutrients (Corporación Autónoma Regional de Cundinamarca et al. 2006). This would cause the upstream points to show higher metal 
concentrations than some of the other points, which was the general tendency shown by the second Bayesian linear model (Fig. 7). Similarly, according to conversations with the residents of the municipality, the Chivor dam discharges very high flows in the Bata river, approximately once a year and for several days, and also during periods of long inflows to the reservoir. The sudden increase in the flow would cause the river to be contaminated in its entirety with the dammed waters by transporting different pollutants and eroded material that comes from the dam and the river basin (MAVDT 2005). This increase in river flow could drag some organisms downstream, possibly disrupting the expected pattern due to spatial migration. However, based on the current data, it is not possible to establish the potential source of higher metal concentrations in the river, given that no predictable results were found at a spatial level.

In addition, given that the sampling points are not far from each other, the snakes could migrate from one point to another, perhaps obscuring the expected spatial pattern. Not many studies have been conducted on Helicops pastazae, and nothing is known about its movement or migration patterns. In Nerodia sipedon, a Neartic aquatic snake, different movement patterns were found depending on the time of the year, presenting changes in its range of activity without occupying an established or permanent home range (Macartney et al. 1988). However, other studies indicate that aquatic snakes have limited home ranges (Campbell and Campbell 2001; Hopkins et al. 1999; Heinz et al. 1980), meaning that H. pastazae may well migrate along the river; in turn, the fact that it does not have relatively fixed home ranges would dilute the expected spatial patterns.

\section{Interspecific comparisons}

Fish from the Characidae family and H. pastazae aquatic snakes have marked differences in diet, occupying different positions in the food chain. The snakes studied are top predators in this ecosystem and are considered opportunistic predators (Almendáriz et al. 2017). These predatory snakes were expected to reveal a higher concentration of heavy metals with respect to fish, as bioaccumulation occurs along the food chain (Heydari and Riyahi 2015). Despite this, there were no significant differences in any metal concentrations in the fish and snake muscle (Fig. 5). The existence of different chemical and kinetic dynamics between species cannot be ruled out, as several researchers have found that different aquatic snakes from the same place of study had different levels of metals in their tissues (Heydari and Riyahi 2015). In fact, a study conducted on a Thamnophis sauritus snake and anura larvae, found that the snakes had significantly lower levels of lead and cadmium than the larvae, indicating that these metals were not biomagnifying to superior trophic levels (Albrecht et al. 2007). It has also been established that lead and cadmium concentrations do not increase along the trophic chain in surface water ecosystems, and these metals have even been found in lower concentrations in the tissues of predatory fish than in lower levels of the food chain (Jezierska and Witeska 2006; Kenšová et al. 2010).

Although some studies indicate a generalist diet for the Helicops genus, there are no studies that determine the diet of H. pastazae, except for a study by Almendáriz, Barriga and Rivadeneira (2017), which states that it may feed on fish of the Hypostomus pyrineusi species. Not having definitive 
information about the diet of this species of aquatic snake in the study area, may mean that preypredator comparisons result in unexpected outcomes.

On the other hand, obtaining statistically equal concentrations between fish and snakes, may indicate that they have some mechanism to rid themselves of heavy metals. Various studies infer that snakes can excrete metals through different mechanisms, such as cesium through feces, skin shedding, and egg production (Campbell and Campbell 2001). High concentrations of chromium, lead, manganese, and mercury have been found in the skin of the Nerodia sipedon aquatic snake compared to all of its other body tissues, suggesting that they can sequester these metals in their skin and excrete them through frequent shedding and, therefore, decrease the pollutant load (Burger 1992; Campbell et al. 2005). Similarly, when comparing the levels of heavy metals between males and females of some snake species, it was concluded that there may be a transfer of metals from the female to the eggshell (Campbell et al. 2005; Burger et al. 2017).

\section{Comparison between tissues}

No significant differences were found between the concentration of different metals in the same tissue (Table 2). However, different $H$. pastazae tissues did bioaccumulate metals differentially (Fig. 7). Cadmium was significantly more concentrated in the liver than the muscle, and lead and chromium had significantly higher concentrations in muscle. This corroborates that tissues have different affinity for certain metals, and that not all tissues are useful for evaluating traces of a particular metal. For example, cadmium appears to be accumulated mainly in the kidney and liver of fish (Jezierska and Witeska 2006; Panchanathan and Vattapparumbil 2006), and fish muscle tissue tends to have the lowest levels of metals (Jezierska and Witeska 2006). The higher concentration of metals in the liver may be due to the fact that it is a metal storage and detoxification organ. However, this does not explain the high concentrations of lead and chromium found in muscle. Some studies show cadmium concentrations to be higher in fish liver, while lead concentrations tend to be homogeneous in the sampled tissues (Zorrilla 2011).

For snakes (Pituophis melanoleucus), it has been found that metals have a greater affinity with the skin. This is especially true for lead, which was found in higher concentrations in the skin than in other body tissues (Burger 1992). In contrast, in alligators (Alligator mississippiensis) the liver had the highest concentrations of cadmium, arsenic, manganese, mercury, and selenium, while the muscle had the highest concentrations of lead and chromium (Burger et al. 2000). The highest concentrations of cadmium in liver were found in aquatic snakes (Nerodia fasciata) fed with contaminated and uncontaminated prey (Hopkins et al. 1999), as in Nerodia spp., where chromium and lead were higher in the skin (Burger et al. 2007), which is consistent with other studies involving Nerodia sipedon (Campbell et al. 2005). A study on marine snakes (Lapemis curtus) showed no differences in concentration between muscle and liver for lead and cadmium. In the present study, in accordance with other studies on aquatic snakes (Burger et al. 2007; Hopkins et al. 1999; Campbell et al. 2005) higher concentrations of cadmium were found in the liver than in the muscle. Likewise, higher concentrations of lead and chromium were 
found in the muscle than the liver, which is consistent with other studies on aquatic snakes and other reptiles (Burger et al. 2000; Burger et al. 2007; Campbell et al. 2005). The diversity of results in the literature shows that it is difficult to predict the tissue where each type of metal will accumulate.

Several studies have found that the liver accumulates high concentrations of metals, regardless of the route of incorporation, and is considered a good indicator of water contamination, since the concentrations that accumulate in this organ are proportional to those found in the environment, especially for copper and cadmium (Jezierska and Witeska 2006). The differential concentration of metals in each tissue could be explained given the differences in metal affinity to sulfhydryl, amino, phosphate, carboxyl, and hydroxyl groups, which are functional groups whose concentration can vary between tissues generating different chemical reactions for the formation of an organometallic compound (Zorrilla 2011). Lead has a high capacity for erythrocyte binding and can easily be substituted with divalent cations (Zuluaga, Gallego and Ramírez 2015); thus, it may, as most heavy metals, have a high affinity with tissues with high blood flow (van der Brink 2004). A high affinity has been found between cadmium and the kidneys, liver, and bones (Zuluaga, Gallego and Ramírez 2015). Given these affinity differences, it can be inferred that tissues vary in their value as bioindicators of different metals.

\section{Snakes as bioindicators}

Compared to similar studies, the present study reflects high levels of metals, especially of lead and chromium, found in different tissues of aquatic snakes. No differences were found between the concentrations of metals found in fish and snakes, which shows that aquatic snakes can be a good indicator of water pollution. For a species to be a useful bioindicator, certain conditions must be taken into account: 1) there is a relationship between tissue contamination levels and dietary exposure (Hopkins et al. 2001); 2) there is a relationship between the levels of contamination in the tissues and the levels in the ecosystem, that is, that the contaminants found in the ecosystem are concentrated at detectable levels in the tissues; and 3 ) the species should reflect the levels of contamination in a specific area (Heinz et al.,1980).

Regarding the first condition, there appears to be no relationship between the levels of heavy metals in the tissues and the levels of metals in their diet. This is due to the fact that, as discussed, there is no verified information on whether the sampled fish are part of the snake's diet. Likewise, several studies have shown that the levels of lead and cadmium tend to be lower in predators than in prey (Jezierska and Witeska 2006; Kenšová et al. 2010). Despite this, finding detectable levels of metals in snake tissue, can help us conclude that they absorb contaminants from their diet, even though the concentrations are not higher than those found in fish. The second requirement is met, as detectable heavy metal levels were observed in the snake tissue, which reflect the contamination present in the ecosystem in which they live. Beyond this, the differences in concentration in each tissue and organism may depend on toxicodynamics (Burger et al. 2007), and on the different rates of incorporation and excretion of metals, and environmental factors, among others. In terms of the third condition, the present study did not show the expected results with respect to each sampling point in the Bata river. This may be due to the 
possibility of snake migration or wastewater discharges, but aquatic snakes did reflect heavy metal pollution differentially at the different sampling points along the river.

Additionally, although specific migration patterns for $H$. pastazae are unknown, aquatic snakes are believed to be relatively sedentary, which may make them good indicators of local contamination (Heinz et al. 1980). The abundance of this species of snake in the Bata river and its long life cycle makes it a good indicator of contamination during long temporal scales (Burger 1992), and it they can be monitored at different points of the river without threatening its population. Apart from this, aquatic snakes are primary or secondary predators in the trophic chain, and may be susceptible to bioaccumulation of environmental pollutants, making them useful for evaluating compounds that can be transferred by trophic mechanisms (Campbell and Campbell 2001). Taking into account all of the above, Helicops pastazae aquatic snakes can be useful bioindicators of heavy metal accumulation at different temporal and spatial scales.

\section{Declarations}

\section{Funding}

The departments of biological sciences, civil and environmental engineering, and chemistry at Universidad de los Andes provided the financial support for this research.

\section{Conflicts of interest}

The authors declare no conflicts of interest.

\section{Availability of data and material}

The datasets generated during and/or analyzed during the current study are stored as Electronic Supplementary Material and available from the corresponding author on reasonable request.

\section{Code availability}

The codes generated and used during the current study are available from the corresponding author on reasonable request.

\section{Author's contribution}

MJHM wrote the research proposal, conducted the data analysis, did the field work, interpreted the results and wrote the initial manuscript. MSRS and AA reviewed and approved the research proposal, results and conclusion, and they commented and contributed to drafting the manuscript. All authors read and approved the final manuscript.

\section{Ethics approval}


The procedures for euthanasia and manipulation of individuals were approved on October 2018 by the Institutional Committee for the Care and Use of Laboratory Animals (CICUAL) by analyzing the animal use format COR_C.FUA_18-016. Individuals were collected under the permit: "Permiso Marco de Recolección de Especímenes de Especies Silvestres de la Diversidad Biológica con Fines de Investigación Científica No Comercial," certified under the research project PR.6.2018.4967 “Integración de rasgos funcionales y moleculares en estudios evolutivos de comportamiento y fisiología," with mobilization permit P04967S3591_N0004.

\section{Consent to participate}

Not applicable.

\section{Consent for publication}

Not applicable.

\section{References}

1. Albrecht J, Abalos M, Rice TM (2007) Heavy metal levels in ribbon snakes (Thamnophis sauritus) and Anuran larvae from the Mobile-Tensaw River Delta, Alabama, USA. Arch Environ Contam Toxicol 53:647-654. https://doi.org/10.1007/s00244-006-0175-3

2. Almendáriz A, Barriga R, Rivadeneira D (2017) Feeding behavior of Helicops pastazae Shreve 1934 (Serpentes, Colubridae, Dipsadinae) in the Ecuadorian Amazon. Herpetol Notes 10:449-451.

3. Burger J (1992) Trace element levels in Pine Snake hatchlings: tissue and temporal differences. Arch Environ Contam Toxicol 22:209-213. https://doi.org/10.1007/BF00213287

4. Burger J, Campbell KR, Campbell TS, Shukla T, Jeitner C, Gochfeld M (2005) Use of skin and blood as nonlethal indicators of heavy metal contamination in Northern Water Snakes (Nerodia sipedon). Arch Environ Contam Toxicol 49:232-238. https://doi.org/10.1007/s00244-004-0098-9

5. Burger J, Campbell KR, Murray S, Campbell TS, Gaines KF, Jeitner C, Shukla T, Burke S, Gochfeld M (2007) Metal levels in blood, muscle and liver of Water Snakes (Nerodia spp.) from New Jersey, Tennessee and South Carolina. Sci Total Environ 373:556-563.

https://doi.org/10.1016/j.scitotenv.2006.06.018

6. Burger J, Gochfeld M, Jeitner C, Zappalorti R, Pittfield T, DeVito E (2017) Arsenic, cadmium, chromium, lead, mercury and selenium concentrations in Pine Snakes (Pituophis melanoleucus) from the New Jersey Pine Barrens. Arch Environ Contam Toxicol 72:586-595. https://doi.org/10.1007/s00244-017-0398-5

7. Burger J, Gochfeld M, Rooney AA, Orlando EF, Woodward AR, Guillette LJ (2000) Metals and metalloids in tissues of American Alligators in three Florida Lakes. Arch Environ Contam Toxicol 38:501-508. https://doi.org/10.1007/s002440010066 
8. Campbell KR, Campbell TS (2001) The accumulation and effects of environmental contaminants on snakes: a review. Environ Monit Assess 70:253-301. https://doi.org/10.1023/A:1010731409732

9. Campbell KR, Campbell TS, Burger J (2005) Heavy metal concentrations in Northern Water Snakes (Nerodia sipedon) from East Fork Poplar Creek and the Little River, East Tennessee, USA. Arch Environ Contam Toxicol 49:239-248. https://doi.org/10.1007/s00244-004-0200-3

10. Corpochivor (1996) Plan Ambiental para el municipio de Santa María, Boyacá. 1Library. https://1library.co/document/q2nd01jq-plan-ambiental-municipio-santa-maria-boyaca.html. Accessed 20 November 2018.

11. Corpochivor (2003) Municipio de Santa María. Esquema de Ordenamiento Territorial: Documento resumen. Santa María. Corpochivor. http://www.corpochivor.gov.co/wpcontent/uploads/2015/11/EOT-Santa-Mar\%C3\%ADa.pdf. Accessed 20 November 2018.

12. Corporación Autónoma Regional de Cundinamarca, Corpochivor, Corpoboyacá, Universidad Nacional de Colombia (2006) Plan de ordenación y manejo ambiental de la cuenca del río Garagoa subcuenca río Machetá en la juridiccion CAR. Corporación Autónoma Regional. https://www.car.gov.co/uploads/files/5ac674d6e8eed.pdf. Accessed 20 November 2018.

13. EPA (1996) Method 3052: Microwave assisted acid digestion of siliceous and organically based matrices. EPA. https://www.epa.gov/sites/production/files/2015-12/documents/3052.pdf. Accessed 20 November 2018.

14. FAO/SIDA (1983) Part 9. Analyses of metals and organochlorines in fish. In: FAO/SIDA Manual of methods in aquatic environment research. Roma, pp 33.

15. Heinz GH, Haseltine SD, Hall RJ, Krynitsky AJ (1980) Organochlorine and mercury residues in snakes from Pilot and Spider Islands, Lake Michigan-1978. Bull Environ Contam Toxicol 25:738-743. https://doi.org/10.1007/BF01985601

16. Henze M, Harremoes P, Jansen JLC, Arvin E (2002) Wastewater Treatment: Biological and Chemical Processes. Berlin.

17. Heydari Z, Riyahi A (2015) Concentrations of trace elements in the kidney, liver, muscle, and skin of short sea snake (Lapemis curtus) from the Strait of Hormuz Persian Gulf. Environ Sci Pollut Res 22:15781-15787. https://doi.org/10.1007/s11356-015-4631-3

18. Hopkins WA., Roe JH, Snodgrass JW, Jackson BP, Kling DE, Rowe CL, Congdon JD (2001) Nondestructive indices of trace element exposure in squamate reptiles. Environ Pollut 115:1-7. https://doi.org/10.1016/S0269-7491(01)00098-7

19. Hopkins, WA, Rowe CL, Congdon JD (1999) Elevated trace element concentrations and standard metabolic rate in Banded Water Snakes (Nerodia fasciata) exposed to coal combustion wastes. Environ Toxicol Chem 18:1258-1263. https://doi.org/10.1002/etc.5620180627

20. Jezierska B, Witeska M (2006) The metal uptake and accumulation in fish living in polluted waters. Soil and Water Pollution Monitoring, Protection and Remediation 69:107-114. https://doi.org/10.1007/978-1-4020-4728-2_6 
21. Kenšová R, Čelechovská O, Doubravová J, Svobodová Z (2010) Concentrations of metals in tissues of fish from the Věstonice Reservoir. Acta Vet Brno, 79:335-345. https://doi.org/10.2754/avb201079020335

22. Lemaire J, Bustamante P, Olivier A, Lourdais O, Michaud B, Boissinot A, Galán P, Brischoux F (2018) Determinants of mercury contamination in viperine snakes, Natrix maura, in Western Europe. Sci Total Environ 635:20-25. https://doi.org/10.1016/j.scitotenv.2018.04.029

23. Macartney JM, Gregory PT, Larsen KW (1988) A tabular survey of data on movements and home ranges of snakes. J Herpetol 22:61-73. https://doi.org/10.2307/1564357

24. Macías PG (2015). Determinación de metales pesados (Pb, Cd, $\mathrm{Cr}$ ) en agua y sedimentos de la zona estuarina del río Tuxpan, Veracruz. Universidad Veracruzana.

https://cdigital.uv.mx/bitstream/123456789/41940/1/MaciasHernandezPatricia.pdf. Accessed 16 April 2018.

25. Mancera-Rodríguez N, Alvarez-León R (2006) Estado del conocimiento de las concentraciones de mercurio y otros metales pesados en peces dulceacuícolas de Colombia. Acta Biol Colomb 11:3-23.

26. Márquez A, Senior W, Fermin I, Martínez G, Castañeda J, González A (2008) Cuantificación de las concentraciones de metales pesados en tejidos de peces y crustáceos de la laguna de Unare, Estado Anzoátegui, Venezuela. Rev Cient 18:73-86. https://zenodo.org/record/160421\#.X-PCHapKhQI

27. MAVDT (2005) Resolución número 1066: Por la cual se establece un plan de manejo ambiental y se toman otras determinaciones. Ministerio de Ambiente, Vivienda y Desarrollo Territorial. http://www.mamacoca.org/docs_de_base/Legislacion_tematica/res_1066_050805.pdf. Accessed 5 May 2019.

28. Panchanathan J, Vattapparumbil IP (2006) Patterns of cadmium accumulation in selected tissues of the catfish Clarias batrachus (Linn.) exposed to sublethal concentration of cadmium chloride. Vet Arh 76:167-177.

29. Queensland Government (2018) Environmental Protection Water Policy 2009- Monitoring and Sampling Manual. Queensland Government. https://environment.des.qld.gov.au/water/monitoring/sampling-manual/pdf/biological-assessmentfish-collection-and-the-dissection-for-the-purpose-of-chemical-analysis-of-tissues.pdf. Accessed 20 November 2018.

30. R Core Team (2013). R: A language and environment for statistical computing. R Foundation for Statistical Computing, Vienna, Austria. http://www.R-project.org/.

31. Segall M, Cornette R, Fabre AC, Godoy-Diana R, Herrel A (2016) Does aquatic foraging impact head shape evolution in snakes? Proc R Soc B-Biol Sci 283:20161645.

32. Uetz P, Freed P, Hošek J (eds.) (2019) The Reptile Database. http://www.reptile-database.org. Accessed 5 May 2019.

33. Van der Brink N (2004) Soil and higher organisms: from bottom-up relations to top-down monitoring. In: P. Doelman, \& H. Eijsackers Vital soil: Function, Value and Properties. pp 235. 
34. Zorrilla MF (2011) Estado del arte sobre la presencia de metales pesados en tejidos y agallas de peces. Universidad Autónoma de Occidente.

https://red.uao.edu.co/bitstream/10614/1637/1/TAA00771.pdf. Accessed 16 April 2018.

35. Zuluaga J, Gallego S, Ramírez CM (2015) Content of $\mathrm{Hg}, \mathrm{Cd}, \mathrm{Pb}$ and As in fish species: a review. Rev Vit 22:148-149. http://dx.doi.org/10.17533/udea.vitae.v22n2a09

\section{Figures}

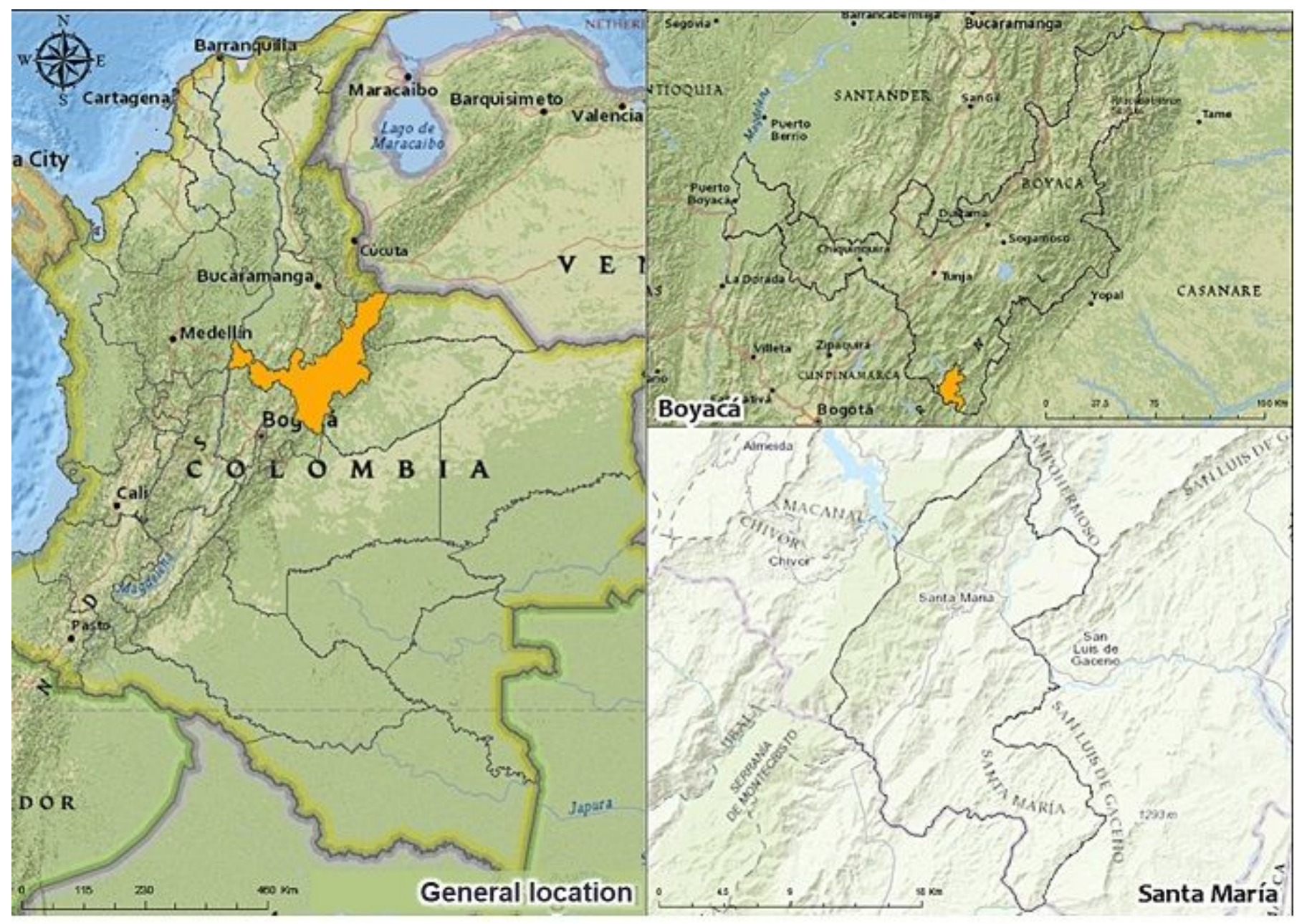

\section{Figure 1}

Location of the study site on the map of Colombia. A detailed map of the department of Boyacá and the location of the municipality of Santa María within this department, where the sampling was carried out. Note: The designations employed and the presentation of the material on this map do not imply the expression of any opinion whatsoever on the part of Research Square concerning the legal status of any country, territory, city or area or of its authorities, or concerning the delimitation of its frontiers or boundaries. This map has been provided by the authors. 

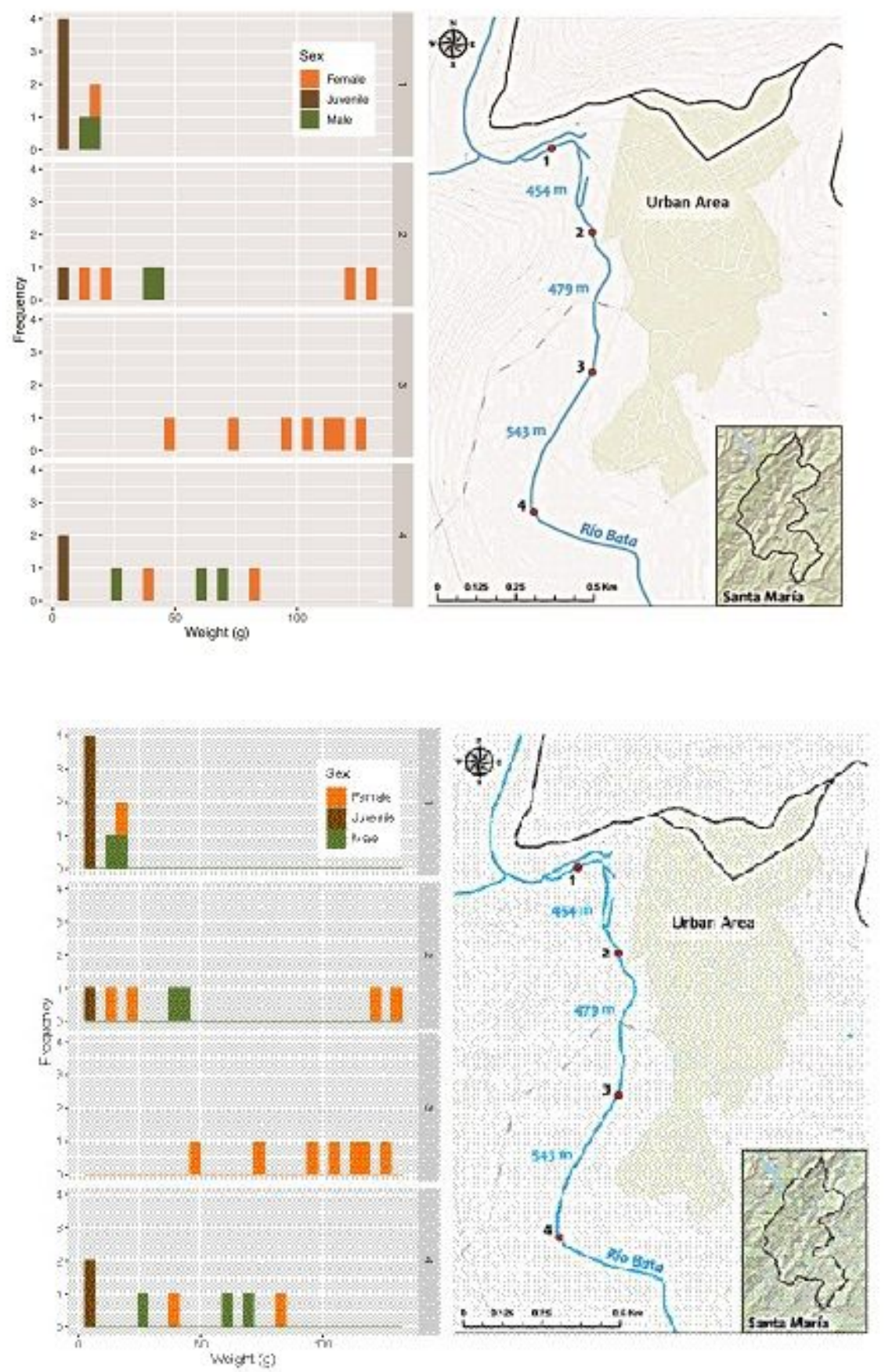

\section{Figure 2}

Sampling design, number of snakes captured and detailed map of the sampling points in the Bata river, located in the municipality of Santa María: Point $1\left(4^{\circ} 51^{\prime} 41^{\prime \prime} \mathrm{N}, 73^{\circ} 16^{\prime} 03^{\prime \prime} \mathrm{W}\right)$, point $2\left(4^{\circ} 51^{\prime} 32^{\prime \prime} \mathrm{N}\right.$, $\left.73^{\circ} 15^{\prime} 57^{\prime \prime} \mathrm{W}\right)$, point $3\left(4^{\circ} 51^{\prime} 19^{\prime \prime} \mathrm{N}, 73^{\circ} 15^{\prime} 57^{\prime \prime} \mathrm{W}\right)$ and point $4\left(4^{\circ} 51^{\prime} 04^{\prime \prime} \mathrm{N}, 73^{\circ} 16^{\prime} 03^{\prime \prime} \mathrm{W}\right)$. Note: The designations employed and the presentation of the material on this map do not imply the expression of any opinion whatsoever on the part of Research Square concerning the legal status of any country, 
territory, city or area or of its authorities, or concerning the delimitation of its frontiers or boundaries. This map has been provided by the authors.
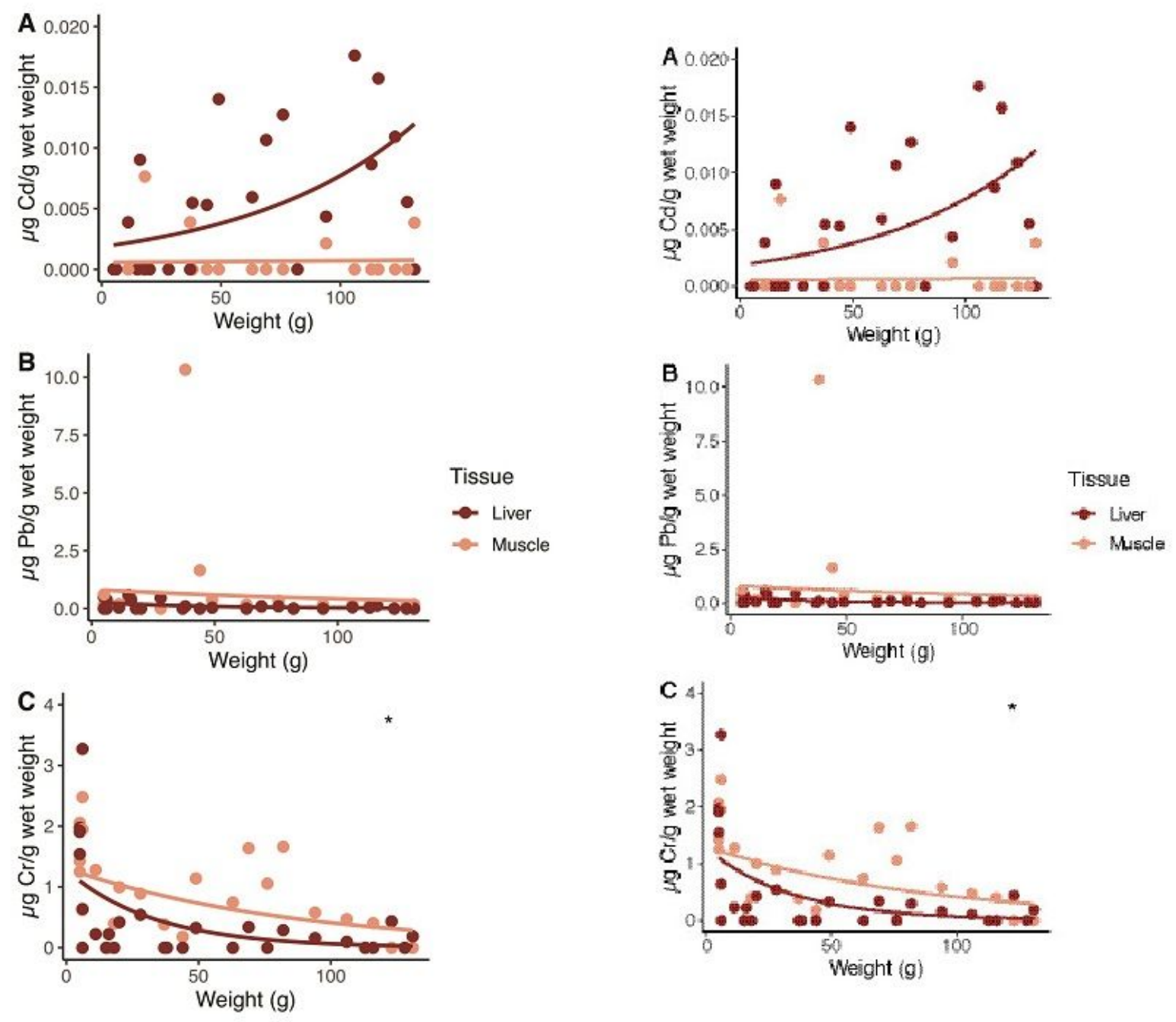

\section{Figure 3}

Relationship between body mass and (A) levels of cadmium, (B) levels of lead, and (C) levels of chromium, in different Helicops pastazae snake tissue 

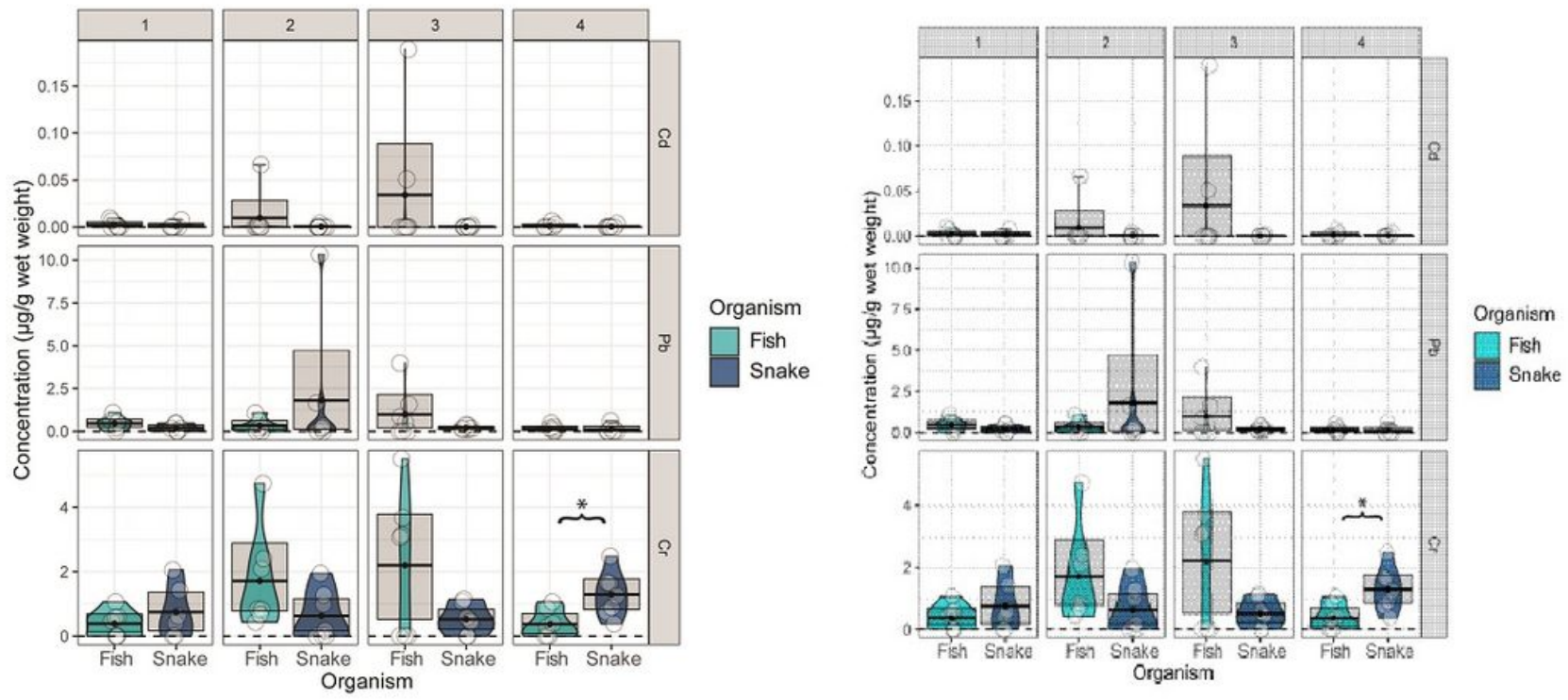

Figure 4

Heavy metal concentration in different sampling points of the Bata river in fish and snake muscle. Asterisk (*): Significant differences between organisms, based on the Bayesian credibility interval of $95 \%$ (boxes) 
A Cd

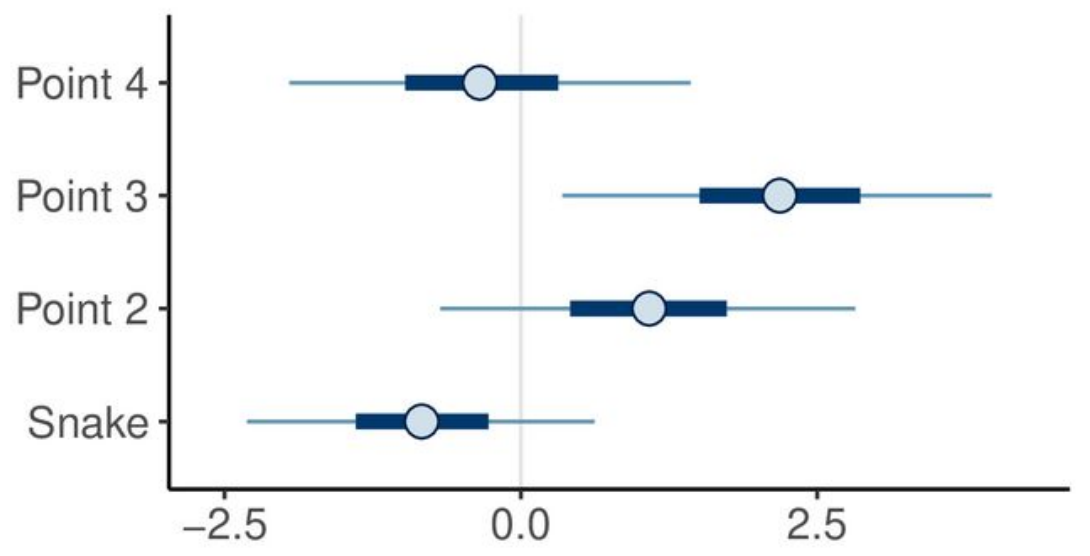

B $\mathrm{Pb}$

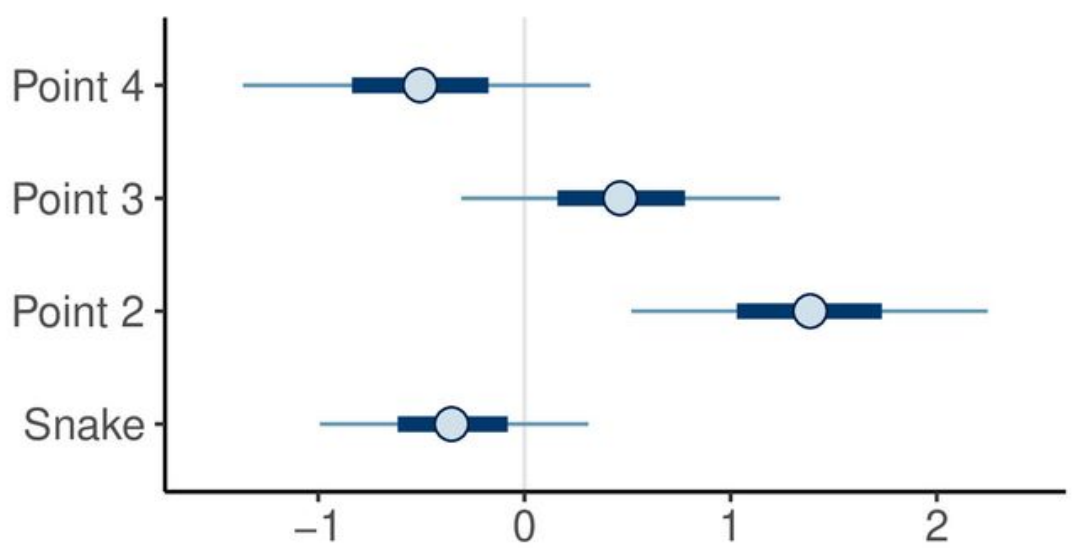

c $\mathrm{Cr}$

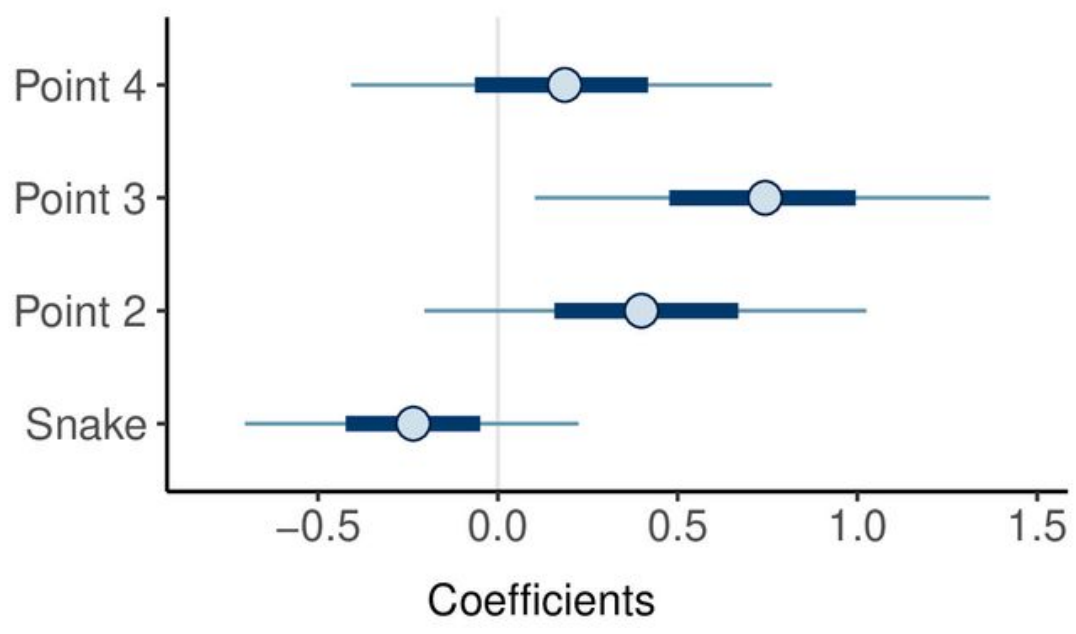

\section{Figure 5}

Magnitude of the effect, according to Bayesian models, of the organism (muscle of fish and snakes) and the sampling point on the concentrations of (A) Cadmium; (B) Lead; and (C) Chromium (Reference line: fish muscle and point 1). 

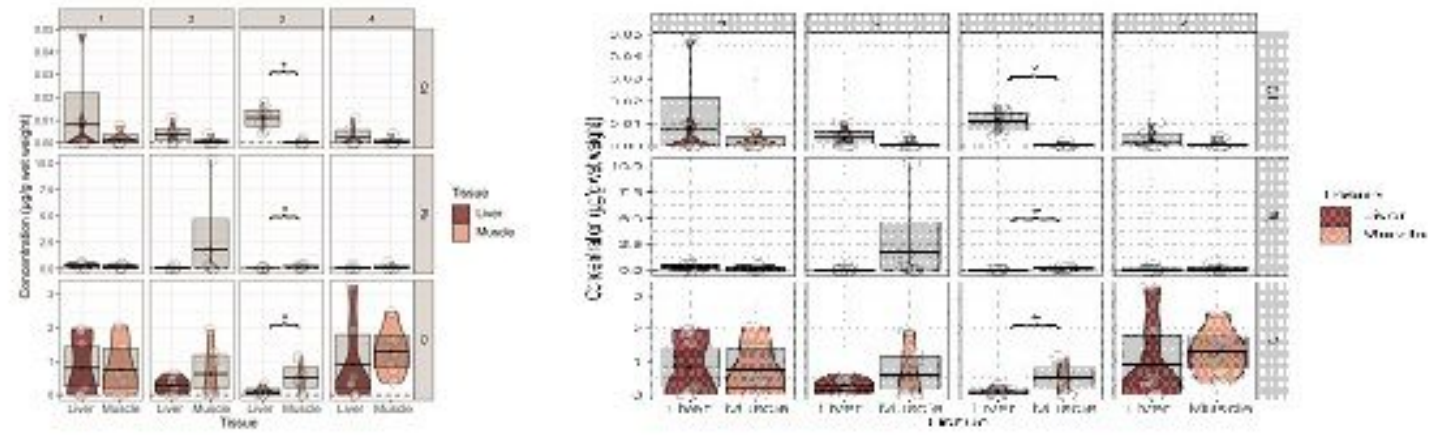

Figure 6

Heavy metal concentration in snake liver and muscle in different sampling points of the Bata river. Asterisk (*): Significant differences between organisms, based on the Bayesian credibility interval of $95 \%$ (boxes) 


\section{A Cd}

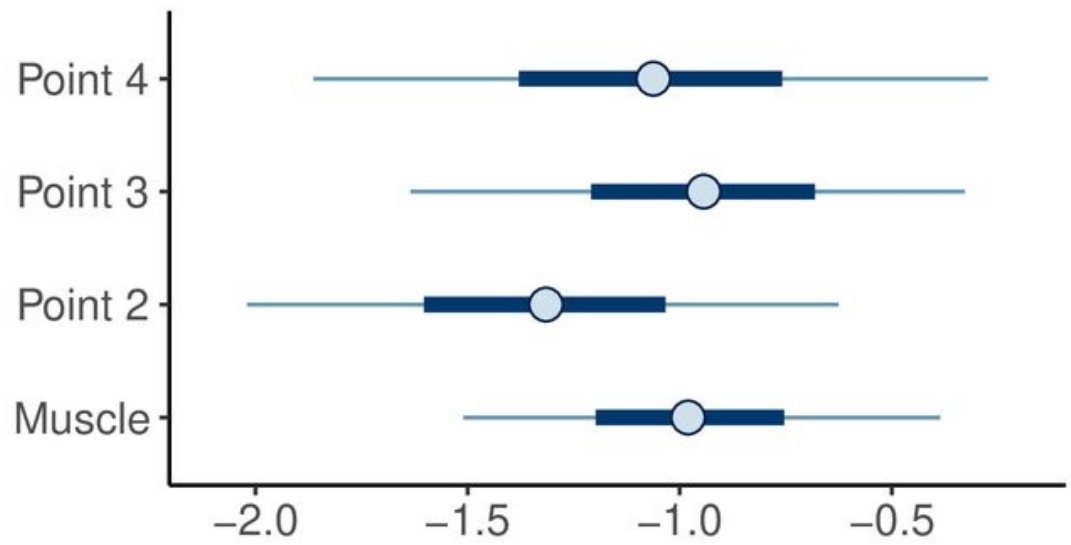

B $\mathrm{Pb}$

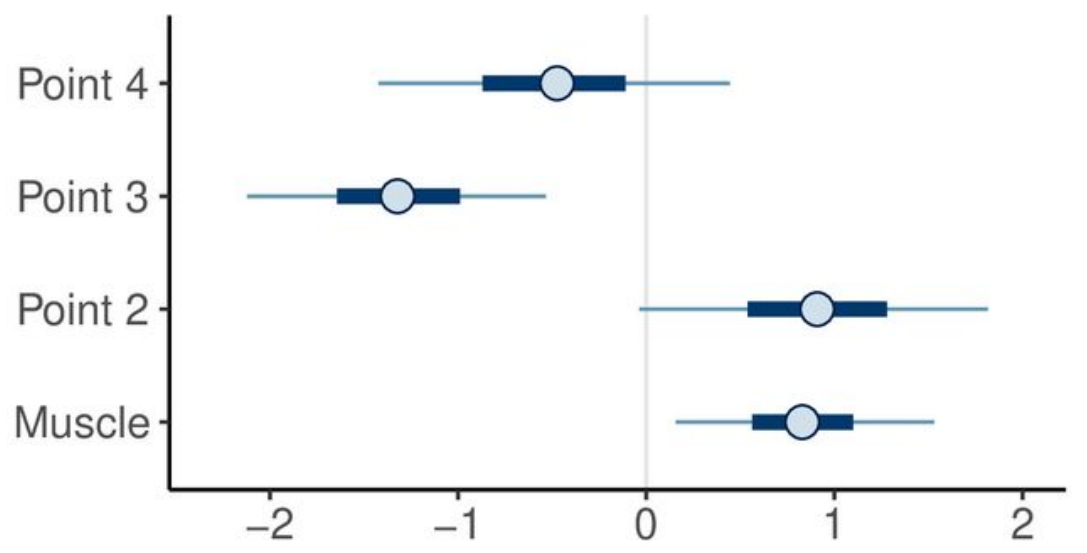

C $\mathrm{Cr}$

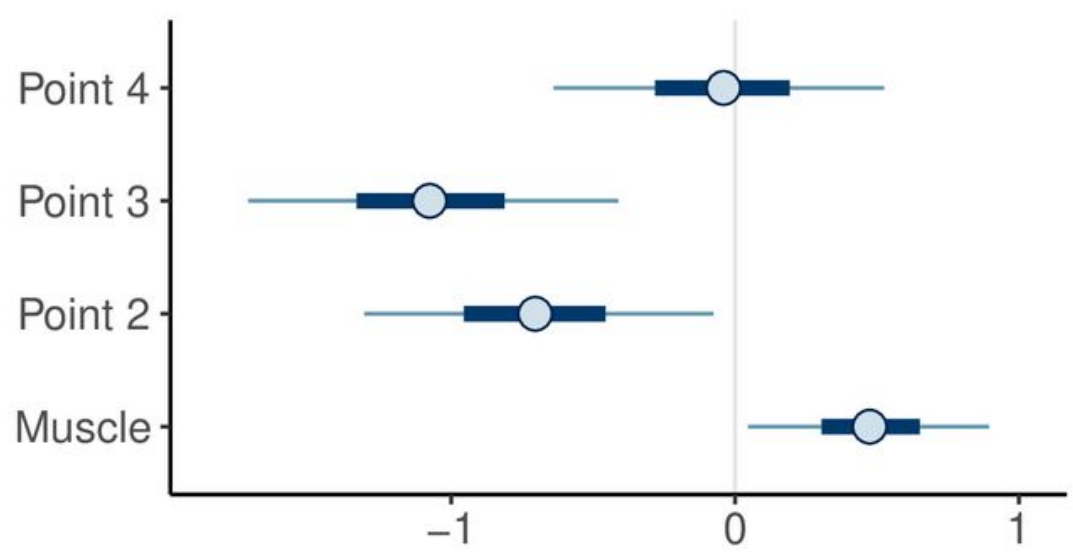

Coefficients

\section{Figure 7}

Magnitude of the effect, according to Bayesian models, of the tissue (snake liver and muscle) and the sampling point on the concentration of (A) Cadmium; (B) Lead; and (C) Chromium (Reference line: liver and point 1). 